\title{
UNDERSTANDING THE COMPLEXITY OF TEACHING THE GENOCIDE AGAINST THE TUTSI THROUGH A CAREER LIFE STORY
}

DOI: http://dx.doi.org/10.17159/2223-0386/2020/n24a2

\author{
Jean Leonard Buhigiro ${ }^{1}$ \\ University of Rwanda, Kigali, Rwanda \\ leobuhigiro@gmail.com \& j.1.buhigiro@ur.ac.rw \\ ORCID No.: 0000-0002-6511-3175
}

\section{Abstract}

The Tutsi, the Twa and the Hutu are three social groups that have enjoyed a monoculture and lived on the same land. In 1994, around one million Tutsi were killed in a genocide organised by the then interim government. It is almost impossible to find any category of people who resisted participating in these killings, which have had tremendous long-lasting consequences. The extent of the killings made the genocide against the Tutsi one of the most researched topics in the history of Rwanda. However, only a few studies have focused on the teaching of this topic. In this article, I argue that the teaching of the genocide against the Tutsi is not an easy task because the teacher has to be careful not only in the choice of the methodology but also in selecting words to be used in a history class and taking into consideration the Rwandan socio-political context. In order to understand the phenomenon of teaching the genocide against the Tutsi, this study adopted a qualitative approach with a career life story methodology. This approach helps us to understand one history teacher's views on his experience of teaching the aforementioned phenomenon. The selected teacher's views cannot be generalised. However, they can give insight into the situation. Rukundo is one of the eleven Rwandan history teachers interviewed in 2013 and again in 2020 in Rwanda during and after my PhD research. This story was chosen because Rukundo is one of the four out of eleven history teachers who indicated that they predominantly used the learner-centred approach recommended by the 2008 and 2010 history curricula and the current competence-based curriculum. The choice of the above participant can help the readers to understand not only the complexity of teaching the genocide against the Tutsi in history in Rwandan secondary schools but also the way the career life story used in this article was constructed to explain Rukundo's lived experience.

Keywords: The Genocide against the Tutsi; Controversial topics; Career life story; Official narrative; Peace Education.

1 I acknowledge the valuable feedback that I received from the members of the Positive Peace in Rwandan Schools Network. 


\section{Introduction}

The genocide against the Tutsi is one of the 20th century's genocides perpetrated in a post-colonial African country. Officially, more than one million Tutsi were killed in a genocide organised by the then provisional government. Even if the genocide is one of the most researched topics in the history of Rwanda, few studies have focused on how this phenomenon is taught in Rwandan secondary schools' history classes.

To understand this phenomenon, a qualitative research design was chosen. Qualitative research with a career life story methodology was constructed to describe how Rukundo reacted the first time he taught about the genocide against the Tutsi and to show how he achieved the aims of the lesson. In addition, the career life story highlights the content covered and how the topic is taught. This particular methodology is useful to understand Rukundo's lived experiences by using his own words and describing the context he is working in.

A Rwandan teacher of history at secondary school, Rukundo was selected from a case study on history teachers' experiences of teaching the genocide in Rwandan secondary schools because he affirmed that he used the participatory approach recommended by the history curriculum (National Curriculum Development Centre, 2008, 2010; Rwanda Education Board, 2015:3-7). This choice can help us to understand how he complied with the philosophy of the history curriculum. As a qualitative study, the perceptions of Rukundo cannot be generalised but they can give an understanding of what is happening in the Rwandan schools. The choice of the above participant can therefore help readers not only to understand the complexity of teaching the genocide against the Tutsi in Rwandan secondary schools but also how the career life story used in this article was constructed to explain Rukundo's lived experience.

The research was guided by the following research questions:

- What are the topics related to the genocide against the Tutsi that are being taught (and not taught) by Rukundo?

- What are Rukundo's aims, methods and experiences in teaching the genocide against the Tutsi?

- What are the factors that led Rukundo to teach the genocide the way he does? 
The research showed that Rukundo skilfully adopted the proposed teaching approaches and adapted them within the socio-political context. He avoided the tension between official interpretations of facts and those held by the common population. By side-stepping an unofficial interpretation of facts, he avoided polarising the class and being accused of being a genocide denier but he also knew how to use favourable situations such as the role of rescuers to teach the genocide in view of building a peaceful Rwanda.

My argument is that teaching the genocide against the Tutsi is a challenging task which requires the teacher to take into consideration the fact that Rwandan society in general is still affected by the effects of genocide. The choice of teaching methods, the selection of words used and the topics to be avoided in plenary discussions should be meticulously done for selfcare and for not harming learners and the society.

\section{Literature review}

The consulted literature highlights certain topics that are sensitive and difficult to discuss in post-conflict societies (Korostelina, Lässig \& Ibrig, 2013; Epstein \& Peck, 2018). The genocide against the Tutsi is one of those sensitive topics that are controversial and difficult to teach (Buhigiro, 2017:190; Nkusi, 2004:55-84). A body of literature highlights various aspects of the genocide including the historical background of the genocide (Newbury, 1995; Prunier, 1997), the controversial role of the international community (Berdal, 2005; Gouteux, 2002; Melvern, 2000), and the context of genocide education in Rwanda (Bentrovato, 2013; Duruz, 2012; Freedman, Weinstein, Murphy \& Longman, 2008; Masabo, 2014; Rutembesa, 2011). It also deals with the teachers' positionality while teaching controversial topics in different contexts. On one hand, there are, for instance, positions which can favour learner-centredness and the development of critical skills. In this regard, teachers can use the balanced approach or they can be Socratic cross-examiners, devil's advocates or risk takers (Lockwood, 1996:2930; McCully \& Kitson, 2005:35; Stradling, 1984:1-12). Using either the balanced approach or Socratic cross-examining, teachers can help learners to deal with different sides of an issue while playing devil's advocate, where teachers take a side of an issue different from that generally accepted with a view to enhancing learners' analytical skills. The debit side does not allow learners to deal with all sides of an issue like the balanced approach. On the 
other side, stated commitment, containment, avoidance, peace-making and indoctrination hinder active reasoning and participation (McCully \& Kitson, 2005:35; Stradling, 1984:1-12; Wassermann, 2011:10). By containment, teachers do not tackle controversial topics, they rather analyse cases from afar that are similar to the ones at home. Avoiders simply skip controversial topics. This is the case of British teachers who do not talk about al-Qaida so as not to be accused of unpatriotic behaviour (Philips, 2008:120). Peacemakers prefer to engage with forgiveness instead of critically analysing the origins of conflicts (Wassermann, 2011:10). With indoctrination, teachers convince learners to adhere to the official version of facts. They can falsify data or teach something without evidence. The procedural neutrality can be on both sides, depending on the teacher's aim (Stradling, 1984:6). It involves adopting a strategy in which the teacher's role is that of an impartial chairperson.

While the Rwandan history curriculum (National Curriculum Development Centre, 2008; 2010; Rwanda Education Board, 2015:37) emphasises a participatory approach and enhancement of learners' competences (knowledge, skills and values), the literature describes advantages and disadvantages of teaching methods and resources used in teaching genocide and other controversial topics. The literature suggests the use of multi-perspectivity and an inquiry approach (McCully, 2010:166; Stradling, 2003:14), contextualisation, use of resource persons, stories including survivors' testimonies in view of micro-history (Lawrence, 2010:51-52; Lawrence, 2012; Lindquist, 2006:217), using parallels with other genocides (Avraham, 2010:S33-SS40; Waterson, 2009:6-7), a crosscurricular approach through art (Thorsen, 2010:191-196); and using information communication technologies (ICT) (Lawrence, 2010:47-53; Totten, 2000:65-71), pictures (Toll, 2000) and field visits (Smith, 2012:97107). What is missing from the literature is how an individual teacher explains her or his experience of teaching the genocide in a post-genocide context so that we can understand the challenges of navigating between enhancing learners' critical skills and respect of the official narrative. As the genocide is a historical event and considering that people use stories to talk about their life experiences, this paper seeks to explore, through a career life story methodology, how a Rwandan secondary school history teacher narrates his experience of teaching the genocide. As Clandinin and Connelly (2009) posit "experience happens narratively... educational experience should be studied narratively" (2009:19). 


\section{Career life story as research methodology}

Career life stories are used in a qualitative research methodology within the interpretative perspective. They are in the broad category of narrative research such as narrative inquiry (Webmaster \& Mertova, 2007), life history (Seetal, 2005), life stories (McAdams, 2008), biographies (Berma, 2010) and autobiographies. Atkinson considers that both life story and life history tell a story about individual life but with a different emphasis and scope. The first "can cover the time from birth to the present" (1998:8), while an oral history can focus on a specific aspect of a person's life. In the case of this research, a career life story can also cover the period from the time a person starts working to the present and it deals with important events, experiences and feelings about their professional life. Career stories have been conducted in other contexts too, including psychology (Jones, 2013:37-53; Tinsley-Myerscough \& Seabi, 2012:742-764). In the same line, some authors highlight the benefits of career life stories. These advantages include, for instance, the ability to explore and communicate experience, entertain, educate, inspire, motivate, put scattered information in the same understandable frame, and as an educational research tool. Life stories help us to know about the subject matter (Webster \& Mertova, 2007:15). By sharing stories, participants understand better what they are doing and obtain greater self-knowledge. It is also a way of "purging, or releasing, certain burdens" (Atkinson, 1998:27). Some teachers feel certain emotions due to sensitive topics and when they talk about their experiences they feel relieved. On the debit side, telling a story involves the issue of memory, which can be deficient or guided by an individual context (McAdams, 2008:246; Riessmann, 1993:22). It is why stories require interpretation - they do not speak for themselves. They can be constructed by using, for instance, written and visual texts, field notes of shared experience, participants' own commentaries, journal records, storytelling interviews (unstructured) and personal philosophies (Riessmann, 1993:47).

In view of gathering data, I employed emergent methods including visual techniques (Crouch \& McKenzie, 2006; Hesse-Bieber \& Sharlene, 2008). Rukundo was given an A4 piece of paper to represent his experience of teaching the genocide (Buhigiro, 2017:169; Buhigiro \& Wassermann, 2017:151-174). Drawing was a hint for him to engage with a difficult topic and to dissipate his emotions. As a drawing can be misunderstood, in this research it was supported by an interview in order to discover the participant's unique perspective through his own voice (Atkinson, 
1998:124). The participant was requested to provide the meaning behind his drawing. A series of pictures from the internet that related to the history of Rwanda and which were selected based on the key aspects of the history curriculum regarding the teaching of the genocide helped Rukundo to talk about the content. In fact, "images evoke deeper elements of human consciousness that [sic] do words" (Harper, 2002:13). More specifically, the selected pictures were in line with the long- and short-term causes of the genocide such as traditional relationships, ethnographic photographs taken under colonial administration and the crashing of President Juvénal Habyarimana's plane. Other aspects included the genocide actors, weapons used during the tragedy and the consequences of genocide. Rukundo was given five minutes to observe the photographs and thereafter asked to choose five photographs most appropriate for his teaching of the genocide. This process helped to identify key aspects in the teaching of this phenomenon.

The analysis of verbal data from the above research methods was done through open coding (Cohen, Manion \& Morrison, 2011:561) and the drawing was first analysed through semiotic analysis in order to understand the complexity of the depiction (Berger, 2004:16; Parsa, 2004:844). Conceptually, semiotics is the study of signs and what they symbolise in daily life. A photograph, a drawing, a gesture or a word are different forms of signs. In this case, I was concerned with the meanings of a drawing depicted by Rukundo. With the visual approach, I considered three types of signs, namely icon, index and symbol (Sebeok, 2001:1011). An icon expresses real meaning. For instance, a photograph of Yuhi III Musinga represents the photographed Rwandan king. An index implies a relationship that it establishes with the object through sensory features (Türkcan, 2013: 601). For example, cumulonimbus clouds which indicate imminent rain. The symbolic meaning is known through convention. For Christians, a cross is a symbol of their religion recalling their redemption through Jesus's crucifixion. As signs can mean different things depending on the time and place, Rukundo's drawing was analysed according to Rwandan culture. The drawing was the data, Rukundo was the analyst and his descriptions were regarded as the primary results. In the second step, they were analysed through open coding.

This analytic strategy of using open coding line by line was guided by the research questions and controversial issues theory (Buhigiro, 2017:130142). The purpose of coding was to describe and reorganise the data by arranging the data into categories. The created categories were used to 
compare things in the same category to develop theoretical concepts and organise the data into broader themes and issues. For instance, certain concepts based on the theoretical ideas such as risk taking, avoiding, peacebuilding, indoctrination, hard experience and teaching methods were used as a priori codes to think about the use of visual methods, in line with controversial issues theory. All common codes such as teaching the genocide using films, teaching the genocide through museums, or teaching the genocide by visiting affected communities were grouped together to form bigger themes such as teaching methods and resources. Other codes such as teaching the genocide for nation-building and teaching the genocide for historical knowledge became the aims of teaching the genocide. Given the sensitivity of the genocide and the research questions, I added other themes, namely the commencement of teaching the genocide and emotions. However, to avoid duplication, the theme about emotions has been dealt with extensively in another work to be published soon (Bentrovato \& Buhigiro, 2021:124-150). The selected themes became the plan to construct the career life story and were used during the presentation of Rukundo's story. More conceptual and interpretative themes were generated. For instance, using resources was adopted in lieu of teaching resources. During the interpretation, the silences were also identified in the data (Fuji, 2009:148). For the first level of the analysis process, the interview was converted into one comprehensible story which serves to illustrate the complexity of teaching the genocide against the Tutsi. More specifically Rukundo's story is composed of a short biography, his first experience in teaching the genocide, selected aims and content, teaching methods and resources. For ethical consideration, anonymity was used as per the consent form and the first person was used to respect Rukundo's own voice. This paper highlights key aspects of the constructed story based on the research questions. The subsequent data presentation followed by discussions is based on themes from the data. This analysis and interpretation of the constructed story constitutes the second level of analysis to allow the reader to better understand the meaning of the story and its context.

\section{How did Rukundo react at the commencement of teaching the genocide?}

The story starts with a brief overview of Rukundo's profile. During my first field research, Rukundo had been a history teacher for 13 years. He 
had completed his bachelor's degree in History with Education at the former Kigali Institute of Education. I met him outside his rural school with limited resources in the Eastern Province. The internet facilities had very modest bandwidth and teachers were obliged to use their cell phones to search for information. Electricity was a problem and the school library was very small. I met him for the second time in a training of teachers of history organised by the National Iterero Commission in December 2019. After the biography, the story goes on to tell of Rukundo's first response to the teaching of the genocide against the Tutsi:

When I was given the course on the genocide to teach the first time I did not find it easy. This was the case because I could not imagine what the learners were thinking about the subject. Moreover, during my first year of teaching history I was challenged on issues related to ethnic groups and the trauma my learners have experienced. In an attempt to come to grip with the challenges I faced I started reading various resources related to the social groups in Rwanda. I also attended a training course organised by the Ministry of Education which empowered me in preventing cases of trauma before they occurred. As a result, I feel that I can teach learners how to speak when they are talking about the genocide; the terminologies they are supposed to use and the terminologies they are to avoid so as not offending their neighbours. For instance, they should not talk about the victims' remains but their corpses or bodies, terms which are more respectful. For the genocide against the Tutsi, they should not use the 1994 civil war, the 1994 upheavals or Rwandan conflict of 1994.

The commencement of teaching the genocide was full of anxieties and commitment to teach this phenomenon. A kind of anxiety about how the learners would react to the subject struck Rukundo. His anxiety was due to the sensitivity of a topic with psychological, social, economic and political awful effects. Even today, the country, learners and teachers are still affected by the past. Thus teachers have to be careful of their own emotions and those of their learners.

Apparently, Rukundo's fear was also due to some aspects like "ethnicity", which are currently considered taboo in Rwandan society. While the current Government of Rwanda is promoting Rwandan citizenship instead of "ethnicity", dealing with such issues can be risky (Bentrovato, 2016:227; Freedman et al., 2008:664). Traditionally, the three social groups - Twa, Hutu and Tutsi - shared the same culture. Under Belgian colonial rule (1916-1962), the porosity of these classes eroded. No one could change from one class to another because they were recorded in identity cards as separate "ethnic groups". After independence, the Hutu-dominated regimes 
(1962-1994) continued to consider Hutu and Tutsi as two separate "ethnic" groups. Thus, no more changes of social class were possible except for those who did it by corruption to gain socio-political advantages and for their own safety. The genocidal killings were guided by these elusive "ethnic" identities. In 1994, power was taken by a rebellion dominated by former Tutsi refugees. In post-genocide Rwanda, the Rwandese Patriotic regime (RPF) is struggling to construct a "unified Rwanda". History is therefore used to show how the colonial administration brought divisionism which was reinforced by the two first republics. "Ethnicity" is thus viewed by the Government as one of the causes of the genocide. This view is criticised by external opponents and some scholars as a strategy of silencing opposition (Bentrovato, 2016:227). However, "ethnicity" cannot be avoided while teaching about the genocide (Gasanabo, 2014:115). The tension between government policy and the teaching of the genocide overwhelmed Rukundo. For his self-care, Rukundo expressed some fears, but as a trained history teacher he was not discouraged. His decision to teach can be understood because history is an examinable subject at the end of the ordinary level (13-16 years) at the national level. Skipping the topic could have led to learners' failure. Moreover, silencing the topic could be viewed as a conspiracy tantamount to genocide denial (Rutembesa, 2011:159).

Some scholars have noticed the commencement of teaching the genocide as risky and horrific (Masabo, 2014:131; Philips, 2008:25). Despite this appalling task, fear and anxiety, which are negative emotions (Alberts, Schneider, Martin, 2012:863), did not prevent Rukundo from working hard to face the challenges related to teaching the genocide. Rather, the mentioned emotions became a motivating factor to him academically and psychologically when preparing the course to efficiently respond to the learners' queries. Pedagogically speaking, before teaching a new topic the teacher thinks about aims, appropriate teaching methods, learners' knowledge and "about what questions or problems are posed by the topic" (Haydn, Arthur \& Hunt, 2001:46).

\section{Why teach the genocide?}

The story goes on to explain the aims of teaching the genocide. In his story, Rukundo described the importance of nation-building and using this strategy: 
My primary aim while teaching the genocide and its related controversial issues is to unite Rwandans and to teach learners the nature of good relationship to the extent that they would not engage in genocide-like atrocities. In line with my primary aim, I teach learners to debate so that they can defend their ideas, make judgement [s] and take decisions. Given my teaching the genocide experience, and my interest in the history of Rwanda, I formed an anti-genocide club here at my school. The aim behind this club is also in achieving my primary aim. The club assists the school in the promotion of a culture of peace, tolerance, reconciliation and patriotism amongst learners in order to transform them into good Rwandan citizens. As part of the activities of the club, learners are also given the chance to debate issues school wide.

The teaching of the genocide against the Tutsi for unity or nationbuilding is one of the stated aims in history curriculums at secondary schools (National Curriculum Development, 2008:3; National Curriculum Development Centre, 2010:5) and one of the broad competences in the new competence-based curriculum (Rwanda, Education Board, 2015a:5). The aims guide teaching and learning. A lesson without aims can lack coherence, hence becoming useless (Haydn et al., 2001: 46). Peace education, with its emphasis on living in harmony and with tolerance and without any distinction of religion or other forms of discrimination that caused the genocide against the Tutsi, is also among the stated aims. Other generic skills such as learners' critical thinking have to be enhanced. Similarly, the differentiation of genocide from inter-ethnic massacres, the involvement of international community and the consequences of the genocide were also part of the aims.

The prioritisation to teach the genocide for nation-building and not for historical knowledge can be problematic given the Rwandan context where one "ethnic" group was systematically killed by another and children from both sides have to study in the same classrooms. This teaching requires enhancing the learners' analytical skills to understand historical evidence in a non-partisan way. The school is therefore one of the best places to foster the culture of unity for nation-building. It hosts a young generation composed of children from all social groups who, through interpersonal relationships, can become unity champions.

Teaching the genocide for nation-building seems to have a twofold focus. First, it can help learners to understand the importance of good relationships, and second it serves as a means of genocide prevention by sensitising learners to avoid genocidal violence. In other words, teaching 
the genocide for genocide prevention is intimately linked to living in peace and harmony as an intention stated in the Rwandan history curriculum (National Curriculum Development Centre, 2008; 2010). For Cole and Barsalou (2006:4), "[H]istory should be taught in a way that inspires young people to believe in their own ability to effect positive changes in society and contribute to a more peaceful and just future." The above aims are also in line with the Government's policies of unity and reconciliation already envisaged in the Arusha Peace Agreement signed in 1993 between the then Rwandan Government and the Rwandese Patriotic Front and reinforced as a national policy after the genocide.

Teaching the genocide so that learners can gain other transferable skills is another aim for Rukundo. In this regard, learners can defend their ideas on the genocide through debate. Learners' debates are done during history class and with the whole school community. Therefore, the idea of debate is also intertwined with genocide prevention. Specifically, genocide prevention cannot be achieved by leaving out any group of learners. Putting this into perspective, school discussions can lead to a community free of discrimination. Learners can also be adequately equipped to face contradicting messages, convey appropriate information and make correct decisions. Thus, teaching the genocide goes beyond the stated aims and reflects on the impact of teaching the matter.

This history teacher also has a sense of historical consciousness when teaching what happened, what is happening and what will happen. This means that the genocide is taught within its historical context, not in isolation, by looking at its causes, sequences and effects. Other scholars also posit that sensitive issues such as the genocide have to be taught so that learners understand why and how these tragedies occurred so that they can contribute to their future prevention (Burtonwood, 2002:69-82; Eckmann, 2010:9). As learners discuss the past objectively, they also avoid biases and stereotyping. In teaching and learning, the aims guide the content.

\section{Which content is covered by Rukundo while teaching the genocide?}

The participant's story focused on the content related to the genocide, including its historical background, genocide-related controversial topics, causes, sequences and its consequences. In the following paragraphs, the 
story is presented in a dialogical way to describe the classroom situation. ${ }^{2}$

For me, genocide is the act of killing a target group of people to the extent that nobody may survive to tell the story. Just it is an extermination of a certain group of people.

The challenging issue is that this is not explained the same way elsewhere where the genocide is equated to a simple war... Other topics that I have to engage in include the planning of the genocide, its execution, the way it was halted and its negative effects on Rwanda.

There are learners who argue that in the neighbouring countries there are many different "ethnic" groups, but they do not kill each other or their neighbours. As a result, it is not accepted by all history learners that the existence of different "ethnic" groups led to the genocide. To them, one cause cannot explain the origins of the genocide.

Another controversial topic that is discussed in my history class when teaching the genocide relates to the issue of a double genocide.

Learner: Teacher, I think there is also another genocide due to the fact that I heard that some Hutu people died in the "Liberation War".

Rukundo: It is not genocide because people who died in the war were not targeted. During the war, there was no planning or intention to exterminate all Hutu. After the genocide, there were few people who were victims of the revenge killings due to the Rwandese Patriotic Front soldiers who were unhappy because of their relatives who were horribly executed. The government made enough efforts to stop this inacceptable attitude. Soldiers who did so were convicted in military courts for their deeds.

Based on my explanation, I am confident that learners are able to differentiate between the actual genocide and the effects of the "Liberation War" and scattered revenge killings which followed the genocide against the Tutsi.

Within the context it is evidenced that the teaching of the genocide raises a conceptual challenge between genocide and war. Rukundo did not refer to the United Nations' conceptualisation of genocide; rather, he provided his own understanding. He refrained from identifying a specific target group. In this regard, he mentioned, "just it is an extermination of a certain group of people". As earlier stated, in pre-colonial Rwanda, the Hutu and Tutsi were two fluid social groups belonging to the same culture. One individual could shift from one group to another. For instance, a Hutu could become a Tutsi after the acquisition of many cows, which was a sign of wealth, or because

2 The "Liberation War" is the civil war that opposed the Juvenal Habyarimana regime and the Rwandese Patriotic Front, Inkotanyi, from October 1990 to 1994, when the latter were fighting mainly for power change and for the Rwandan refugees return to their homeland. 
of a political promotion. However, this was not a general rule because all cow owners or political leaders were not Tutsi only, some Hutu could have more cows than Tutsi, and some Tutsi were agro-pastoralists. The situation was quite complex and it kept changing with time. It is why Rukundo does not consider Tutsi as an "ethnic" group and thus his understanding does not match with any category of people mentioned by the United Nations conceptualisation. For the latter, genocide is conceptualised as specific acts committed with the intent to destroy, in whole or in part, the national, ethnic, racial or religious groups (Jørgensen, 2001:285-313). Some scholars considered the United Nations' definition incomplete (Kissi, 2004: 115133; Straus, 2001:349-375). For instance, the extermination of political groups during the Second World War is not included in a view of hiding pro-Soviet Union regimes' atrocities. Silencing "ethnic" groups in the case of Rwanda is prudent because it can contradict the Government policy of promoting a unified Rwandan identity (Freedman et al.: 2008:664). From the same perspective, Rukundo preferred not to comment on the learners' case of neighbouring countries where "ethnic" problems were discussed openly (Vandeginste, 2014:263-277). Teaching history this way promotes a docile citizen but does not help a critical learner. It is also unsafe for a teacher to deal with issues that are not discussed publicly.

In the case of Rwanda, equating the genocide against the Tutsi to a simple war is very sensitive. This is because the opponents of the Rwandese Patriotic Front-led regime wanted to exploit what was officially called individual and isolated cases of revenge perpetrated by some soldiers to connect them to a deliberate extermination (Belof, 2014:269), thus attracting the attention of the international community. The teacher-centredness adopted by Rukundo on this matter is evidence of the sensitivity of the topic. Rukundo did not take the risk to raise this sensitive issue: it was raised by a learner. In addition, Rukundo did not allow the learners to discuss it. He preferred to tell them which narrative to adopt. This preaching was aimed at protecting the teacher's and learners' safety by avoiding the propagation of unofficial narratives which could be considered as genocide denial and divisionism. In Rwanda, the crime of genocide ideology is used as a pretext to skip or avoid discussing some aspects of the genocide that would lead to a prosecution for an unintentional crime. According to the law, the negation of genocide includes, for instance, the support for a double genocide theory for Rwanda or a misconstruing of the facts to mislead people (Republic of Rwanda, 2013:38-39). 
The idea of the existence of "ethnic" groups as the cause of the genocide was challenged by learners. For them, other neighbouring countries have many tribes or "ethnic" groups, but they do not engage in wars or genocidal acts. In reality, the causes of the genocide, like any other historical event, are multiple. One learner made it clear by adding that the cause was "the exclusion against the Tutsi and people from southern regions in education and some public sectors positions". Other causes of the genocide, such as the role of media, international community influence and the former regime's fear of losing power due to the pressure of the war launched by the Rwandese Patriotic Front, were not pointed out by Rukundo. This silence can be understood in as much as the quota policy propounded by political leaders in the early 1960s implied exclusion of Tutsi. Consequently, learners pointed out the prominent cause. However, teaching the genocide without mentioning other causes is deficient and can lead learners to keep their misconceptions on the matter.

Rukundo's avoidance to discuss the double genocide problem concurs with McCully's (2012:145-159) scepticism about using a multi-perspective method to analyse a recent contentious history still coupled with trauma and anger. In Rwanda, the genocide is still fresh in the minds of a good number of Rwandans and some of them are either suffering from posttraumatic stress disorder (Munyandamutsa, Mahoro, Gex-Fabry \& Eytan, 2012:n.p.; Sibomana, 2017:13) or are afflicted by other consequences of the genocide, such as the loss of loved ones or properties.

\section{How is the genocide taught?}

Rukundo's story continues with the teaching methods used in teaching the genocide. In the following extract, the participant explains different strategies he uses to deliver this sensitive topic:

Given my academic qualification and experience, since the beginning of my teaching career, I like using interactive methods when teaching genocide and its related controversial topics. It helps learners to internalise their content and some activities like group work increase their unity. In the introduction of my lesson on the causes of the genocide, I ask the learners questions about the definition of genocide according to their understandings. I also ask questions about pre-colonial Rwandan society so as to determine what they know mainly as causes of disunity. I follow the same approach for the body of the lesson. The learners can give answers according to what they know... 
Sometimes, I divide the learners in my history class into groups so that they can analyse stories related to the genocide and understand specific decisions. For the planning of the genocide, for example, I, mainly use a study done by the Rwandan Parliament (Parliament, The Senate, 2005). It deals with the genesis and development of the genocide ideology. It shows for instance how colonial racism changed into national ethnicity, the role of political parties, and the role of propaganda, and the description of enemy, namely the Tutsi in the post-colonial period. For this topic, I use a teachercentred approach because the document gives a series of hatred policies and extract of speeches. It is done in this way because my main aim here is not to help learners internalise this discrimination but to understand how bad policies can lead to disastrous events.

The use of teacher-centredness to talk about some topics including "ethnic" identities and hatred policies can be explained by Rukundo's knowledge of Rwandan society. In fact, there were divergent discourses about "ethnic" identities during and after the genocide as stated earlier. The study mentioned was based on European racial theories that could negatively influence learners because these theories were exploited to fabricate hatred policies. Thus, Rukundo avoided learner-centredness. The adoption of discussion on "ethnic" identities could generate the flow of uncontrolled information, which could either polarise the class or harm certain learners. "Ethnic" identities are side-stepped in the history curricula in order to avoid the recurrence of divisionism (National Curriculum Development Centre 2008; 2010; REB, 2015). However, "ethnic" identities are mentioned in public for a purpose but are not openly discussed. For instance, in public talks, "ethnic" identities can be referred to in order to show the impact of hatred policies or genocidal processes. Rukundo complied with the curriculum and official narrative by not engaging with "ethnic" identities and hatred propaganda by using critical pedagogical methods. Rukundo used teacher-centredness, which can be categorised as teachers who can deal with difficult or abstract ideas instead of avoiding them (Haydn et al., 2001:73; Totten, 1999:36-39).

Despite this teacher-centredness, Rukundo adopted a learner-centredness through stories. The following paragraphs are extracts of a story about a young person, the narrator, describing his life during the socio-political changes of the early 1990s, characterised by the re-instauration of a multiparty system and the war between the Rwandese Patriotic Front and the then Government. It is used by Rukundo to teach the genocide. 
Before the genocide erupted, I was very young and strong. I was a member of our political party youth organisation. We used to accompany the party leaders in political meetings. Youth, we were sensitized to be ready to secure our country. When the genocide started, we felt that it was courageous to kill Tutsi as we were told that they were Rwandese Patriotic Front accomplices as a way of protecting our country. I thought we were really protecting our country. May God forgive me!

During the Gacaca courts, I pled guilty and confessed to have killed people in my village. The Gacaca courts reduced my sentence and I was released. For the moment, I participate in activities of helping my neighbours who were affected by the genocide and I pray so that no more people be involved in such hate deeds against Tutsi or one's neighbour.

I ask at once a series of questions to the learners after two minutes of reflection, the latter start giving their views: If it was you who were young member of the political party, what would you have done at the eruption of genocide? Did those involved do something good? The decisions taken was it done with judgment? What do you think about the decision to plead guilty? Was it a firm decision or a strategy to be released?

Such questions help learners to enhance their thinking skills in a neutral manner. This procedural neutrality position helped the learners to understand the complexity of the execution of the genocide. However, Rukundo's questions had some limitations because they were not interpretative. Such questions require the use of evidence and inferences. In this case, evaluation of the story with the available evidence and historical knowledge was not done. Rukundo also failed to put the character in his historical context. Apparently, the proposed questions were aimed at teaching learners to be able to take responsible decisions which, in the view of genocide prevention, thus insisted on the history's educative value.

What is emerging from the story is that by using stories Rukundo wanted to develop a series of skills and values. For instance, the learners were given time for reflection before responding so they could develop their analytical skills. Discussing stories in groups was intended to help learners to be responsible for their own education. Learning the history of the genocide in that way also fostered a climate of collaboration, mutual respect and tolerance (Prince \& Fielder, 2006:123). In addition, learners could understand that normal people could become perpetrators (Eckmann, 2010:9). Through truth-telling, stories can contribute to reconciliation as was the case during post-war Polish-Jewish relations due to the narratives of the righteous (Bilewicz \& Jaworska, 2013:162). 
Considering theories about controversial issues, the use of discussion by Rukundo can be connected to the nurturant facilitator (Lockwood, 1996:499) because he did his best to engage learners on values clarification within a safe environment. However, the story was not crafted by learners to enhance their generic skills and participation. Avoiding the learners' stories did not totally engage the learners' participation when teaching a contentious topic. Apparently, sometimes Rukundo took the risk of asking sensitive questions. This was the case when he himself pleaded guilty, which could have brought undesirable narratives into the history class. $\mathrm{He}$ proposed another question which could suggest an alternative answer to guide learners in their choice. A kind of learner-centredness was practised in view of the teacher's safety and that of the learners.

\section{Which resources?}

Rukundo's story went on by unfolding teaching aids which helped him to achieve his teaching aims. These included, amongst others, pictures, maps, films and resource persons. Pictures depicting different actors in the genocide, such as the United Nations or French troops during the 1990s, orphans and other genocide consequences and the hope for Rwandans to live a better life in the future.

Regarding the use of ICT, Rukundo narrated how films and the internet were used in the history class:

To concretise the event, I used also to screen films such as Tuez-les tous to show learners how the genocide was executed and how the Interahamwe militiamen killed people. Pedagogically speaking, in my view, with films learners observe and listen at the same time to what happened. They are requested to write a summary of the film. They are also given homework. This also helps them to relate to what they have learnt in class.

Teacher: In your today's homework respond briefly to the following questions to be submitted in our next history lesson: Show if colonists contributed to sow divisionism in Rwanda. Explain the role to propaganda and how Radio Télévision Libre des Mille Collines contributed to the killings. By considering J.P.Chrétien's comments explain the role of elites. Discuss the role of France in Rwandan conflict and finally discuss if the film conclusion contribute to the Rwandan reconciliation.

I also urge my history learners to use sources from the internet while preparing, for example, their presentations. But the learners are not free to use any website - only the recommended ones such as the documents on the National Unity and Reconciliation websites. 
The use of ICT has been identified as a theme in this story. Rukundo was worried by the learners visiting his website in his absence. He took precautionary measures relating to the learners' use of the internet. On the one hand, this decision can be seen as a way of preventing learners from harm by watching traumatising films. On the other hand, learners can be influenced by genocide deniers' websites. Alongside the internet, films were also used. By paying attention, films were an opportunity for learners to enhance their skills and values, including decision-making, writing and listening to others' views. In brief, it was a chance to enhance their visual literacy. It could also help learners to become human rights activists. Enhancing the learners' critical thinking due to interpretative questions asked by Rukundo was another aim. However, by selecting specific websites, learners should get some preliminary techniques to critique history in order to analyse a large number of electronic sources. The most important thing is not to hide some sources, but rather to be able to understand why different people have different views. Missing such skills can lead to lack of tolerance and respect of others' views.

The benefits and disadvantages of ICT have been discussed in history education by some authors (Haydn 2000:102-134). What Rukundo did to achieve his aim of building a better Rwanda and enhancing the learners' skills is supported by the literature. Totten (1987:63-67), for instance, encouraged the use of video presentations as they could make a topic real for learners. More importantly, the learners were obliged to try to see and critically interpret the images so as to gain literacy skills. Thus, films were not used for entertaining learners; rather, they were used to understand content, enhance some skills and build a better Rwanda. The lack of other ICT-related activities, such as computers for designing databases on genocide issues and PowerPoint presentations, can be explained by the shortage of resources in Rwandan schools. Preventing learners from using any website can be seen as a kind of indoctrination instead of protecting them against unofficial narratives.

Concerning museum and field study as resources, the story runs as follows:

Before the visit, learners are requested to write in their notebooks main ideas and questions to the local leader or elder. Back at school, they are requested to find similarities or particular aspects of the told testimonies. Similarly, my class visits to the Rugarama memorial site and families that have been affected by the genocide discuss how they have been assisted 
and live with their neighbours. In my view, learners are interested in knowing how people were reunited after horrible events that had occurred. After such visits, learners are given time to explain what they have seen and to reflect on how the genocide has impacted on people. Moreover, according to me, by visiting families they get to realise that there is a hope for the future and that Rwandans will be united. The reconstruction of the country is one of the ways that can show affected learners that they are not alone. However, I admit that visiting sites can be a problem as it requires transport which not every learner can afford. The study tours were adopted in my second year of experience after identifying where and who to visit and the school planning financially for it.

The development of understanding a genocide of the past can be done by visiting museums and genocide memorials. The new competence-based curriculum does not mention the use of museums in the unit on genocide (Rwanda Education Board, 2015a:32-33, 2015b:26-27). During the study tour, invited resource persons' choices have a double objective. On the one hand, choosing a local leader could transmit an official narrative to learners. On the other, choosing an elder could serve to teach learners from her or his lived experience. In this case, Rukundo accepted that multiple views could arise. For instance, people from the targeted Tutsi social group were killed but also political opponents and rescuers suffered during the genocide. Thus, learners got to understand that people had different experiences during the genocide. Genocide memorials are also used to increase the learners' historical understanding and critical skills by comparing testimonies with other sources. In other words, study tours to museums and local communities can be a way of reflecting on the local history and helping learners to gain direct information about reconciliation by empathising with affected communities. According to McAllister and Irvine (2002:433), "Empathy can potentially foster openness, attentiveness, and positive relationships." But the danger is that learners might overidentify themselves with either the victim or the perpetrator (Waterson, 2009:7). The choice of the person to visit in the community was, in the case of this study, meticulously done. If selection is not well done, it is not easy to achieve the learning outcome of the study tour. It denotes lack of experience and the subject matter changes into amusement. Briefly, the study tours proved to Rukundo that the genocide could be taught beyond the classroom to increase the learners' participation and development of their skills and values. 


\section{Conclusion}

In post-genocide Rwanda, the use of the participatory approach proved to be challenging for Rukundo even though it was recommended by the history curriculum. The participant refrained from pedagogically engaging learners with certain topics such as double genocide, "ethnic" identities and race. Fear of being accused of genocide denial dictated the use of lecture mode for this topic for which the official legal version provides a clear positioning. Thus, multi-perspectivity does not seem to be a panacea in history teaching. Given the context, discussing the aforementioned topics could polarise the classroom by bringing harmful messages into a society still affected by the genocide consequences. Adopting a self-care attitude does not only aim at respecting the official narrative, but also to avoid harming learners and the community. Thus, compliance with the official narrative, the societal sufferings and the way of interpreting the curriculum guides how the Rwandan genocide and related topics are taught. This means that teachers should have the capacity to critique the syllabus and use resources in line with the learners' specific social and cognitive needs.

Teaching the genocide does not only aim at enhancing historical knowledge by putting the genocide into its wider context for discussing causes, sequences and effects. Given the Rwandan context, a range of activities adopted by Rukundo aimed at helping learners to become responsible citizens who could responsibly take decisions. With the same perspective, the learners are the first trained to reflect on what they are going to do. Thus, teaching the genocide goes beyond historical knowledge; rather, it aims at imparting values and behaviours which can be used to cure Rwandan society's scars to learners.

In terms of controversial issues theory, the story proved that Rukundo's positions kept changing with regard to the topic or aim to be achieved. Some positions such as the teacher as Socratic cross-examiner (Lockwood, 1996:29-30) or taking a balanced approach (Stradling, 1984:6) were adopted while asking questions to train learners to make decisions. In the face of hard topics, including those punishable by Rwandan law, a commitment to adopting the official version, which was tantamount to indoctrination, was embraced. However, some positions, such as risk-taking or playing devil's advocate, were not adopted by Rukundo. Rather, he cautiously preferred to avoid bringing uncontrollable discussions into class. This scepticism shows that Rwandan society is still fragile and teaching the 
genocide cannot blindly follow the proposed participatory approach. By taking this risk, the teacher can be plunged into genocide denial or polarise the classroom. The challenge is that imposing one narrative can also lead to learner anger and frustration. Teaching the genocide thus poses a double challenge: developing the learners' critical skills and respecting the official narrative. Instead of preventing learners from dealing with some issues or using some sources, an effort should be made to teach them to analyse evidence, including a range of electronic sources. Learners should be taught to look for evidence and identify its strengths and weaknesses. In order to enhance critical skills while discussing contentious topics, Rwandan schools should be considered safe spaces where such discussions can take place and teachers should be constantly trained and sensitised so that schools become venues for constructive confrontation. This means that they should allow learners to increase their knowledge through discussion, but the community at large should also be involved in this process to a certain extent, otherwise learners will lack the skills to discuss hard contentious topics and discern why people have different views. This gap can lead to lack of tolerance of divergent views hence sources of other conflicts.

\section{References}

Alberts, HJEM, Schneider, F \& Martin, C 2012. Dealing efficiently with emotions: Acceptance-based coping with negative emotions requires fewer resources than suppression. Cognition \& Emotion, 26(5):863-870.

Avraham, D 2010. The problem with using historical parallels as a method in Holocaust and genocide teaching. Intercultural Education, 21(S1):S33-S40.

Atkinson, R 1998. The life story interview. Qualitative research methods, 44. London: Sage Publications.

Beloff, J 2014. Who is the real hero of Hotel Rwanda? In: JD Gasanabo, MM Ensign \& DJ Simon (eds.). Confronting genocide in Rwanda: Dehumanization, denial, and strategies for prevention. Bogota: Apidama Ediciones Ltd.

Bentrovato, D 2013. Narrating and teaching the nation: History, identity and the politics of education in the Great Lakes Region of Africa. Unpublished thesis. Utrecht: University of Utrecht. 
Bentrovato, D \& Buhigiro JL 2020. Mediating emotive knowledge in the presence of historical trauma: Emotions in hitory teachers' everyday discourses and practices around genocide education in Rwanda. In: D Bentrovato, J Wassermann (eds). Teaching African history in schools. Experiences and perspectives from Africa and beyond. Leiden, Boston: Brill Sense.

Berdal, M 2005. The United Nations, peacebuilding, and the genocide in Rwanda. Global Governance: A Review of Multilateralism and International Organizations, 11(1):115-130.

Berger, A 2004. Media analysis techniques. Thousand Oaks, California: Sage Publications, Inc.

Bilewicz, M \& Jaworska, M 2013. Reconciliation through the righteous: The narratives of heroic helpers as a fulfilment of emotional needs in Polish-Jewish intergroup contact. Journal of Social Issues, 69(1):162-179.

Buhigiro, JL 2017. The experiences of Rwandan secondary schools' history teachers in teaching the genocide against the Tutsi and its related controversial issues. Unpublished PhD thesis. Durban: University of KwaZulu-Natal.

Buhigiro, JL \& Wassermann, J 2017. Revealing professional development needs through drawings: The Case of Rwandan history teachers having to teach the genocide against the Tutsi. International Journal of Research on History Didactics, History Education and Culture, 38:151-174.

Burtonwood, N 2002. Holocaust memorial day in schools-context, process and content: A review of research into Holocaust education. Educational Research, 44(1):69-82.

Clandinin, DJ \& Connelly, FM 2000. Narrative inquiry: Experience and story in qualitative research. San Francisco: Jossey-Bass.

Cohen L Manion L \& Morrison K 2011. Research methodology in education (7th edition). New York: Routledge.

Cole, E \& Barsalou J 2006. Unite or divide? The challenges of teaching history in societies emerging from violent conflict, 1-16. Available at http://www. usip.org/sites/default/files/resources/sr163.pdf. Accessed on 10 April 2020. The logic of small samples in interview-based qualitative research. Social Science Information, 45(4):483-499.

Crouch, M \& McKenzie, H 2006. The logic of small samples in interview-based qualitative research. Social Science Information, 45(4):483-499. 
Duruz, G 2012. Speaking history in present Rwanda.Unpublished MA thesis. Kigali: National University of Rwanda, Kigali.

Eckmann, M 2010. Exploring the relevance of Holocaust education for human rights education. Prospects, 40(1):7-16.

Epstein, T \& Peck, C 2018 (eds). Teaching and learning difficult histries in international contexts: A critical socio-cultural approach. New York: Routledge.

Fuji, LA 2009. Interpreting truth and lies in stories of conflict and violence. In: C Sriram, J King, J Mertus, O Martin-Ortega \& J Herman (eds.), Surviving field research: Working in violent and difficult situations. New York: Routledge.

Gasanabo, JD 2014. Dehumanization and anti-dehumanization in schools. In: JD Gasanabo, DJ Simon, MM Ensign (eds.). Confronting genocide in Rwanda: Dehumanization, denial, and strategies for prevention. Bogota: Apidama Ediciones Ltd.

Gouteux, JP 2002. La nuit rwandaise: l'implication française dans le dernier génocide du siècle. Paris: Editions Izuba/L'Esprit frapeur.

Harper, D 2002. Talking about pictures: A case for photo elicitation. Visual Studies, 17(1):13-26.

Haydn, T 2000. Information and communication technology in the history classroom. In J Arthur, R Philips (eds.). Issues in history teaching. London: Routledge Falmer. Taylor \& Francis Group.

Haydn, T, Arthur, J \& Hunt, M 2001. Learning to teach history in the secondary school. A companion to school experience. London: Routledge Falmer Taylor \& Francis Group.

Hesse-Bieber, S \& Sharlene N 2008. Pushing on the methodological boundaries. The growing need for emergent methods within and acrss the disciplines. In $\mathrm{S}$ Hesse-Bieber \& N Sharlene (eds.). Handbook of emergent methods. New York: The Guilford Press.

Jørgensen, N 2001. The definition of genocide: Joining the dots in the lights of recent practice. International Criminal Law Review, 1(3):285-313.

Kissi, E 2004. Rwanda, Ethiopia and Cambodia: links, faultlines and complexities in a comparative study of genocide. Journal of Genocide Research, 6(1):115-133.

Korostelina, KV, Lässig, S \& Ibrig, S (eds) 2013. History education and post-conflict reconciliation. Reonsidering joint textbook projects. London, New York. 
Lawrence, A 2010. Being historically rigorous with creativity: how can creative approaches help solve the problems inherent in teaching about genocide? Teaching History (140):47-53.

Lawrence, A 2012. Why study Rwanda when we have learned about the Holocaust? In: P Cowan \& H Maitles (eds.). Teaching controversial issues in the classroom: Key issues and debates. London: Bloomsbury Publishing.

Lockwood, AL 1996. Controversial issues: The teacher's crucial role. Social Education, 60(1):499-518.

Masabo F 2014. Educating about the history of genocides in Rwanda. In K Fracapane \& M Haß (Eds.), Holocaust education in a global context. Paris: UNESCO.

Melvern, L 2000. A people betrayed: the role of the West in Rwanda's genocide. London: Zed Books.

Munyandamutsa, N, Mahoro, NP, Gex-Fabry, M \& Eytan, A 2012. Mental and pshychitrical health in Rwanda 14 years after the genocide. Social Psychitry and Psychiatric Epidemiology, v47(11), 1753-1761. Available at https:// doc.rero.ch/record/313196/files/127_2012_Article_494.pdf. Accessed on 29 October 2020.

National Curriculum Development Centre 2008. History program for Ordinary Level. Kigali: Ministry of Education.

National Curriculum Development Centre 2010. History of Rwanda. A participatory approach. Teacher's guide for secondary schools. Kigali.

McAdams, DP 2008. Personal narratives and the life story. In: OP John, RW Robins \& L. A Pervin (eds.). Handbook of personality: Theory and research. Third edition. New York: Guilford Press.

McAllister, G \& Irvine, JJ 2002. The role of empathy in teaching culturally diverse students a qualitative study of teachers' beliefs Journal of Teacher Education, 53(5):433-443.

McCully, A 2010. What role for history teaching in the transitional justice process in deeply divided societies? In: I Nakou \& I. Barca (eds.). Contemporary public debates over history education: A volume in International Review of History Education. Charlotte: Information Age Publishing.

McCully, A 2012. History teaching, conflict and the legacy of the past. Education, Citizenship and Social Justice, 7(2):145-159. 
Newbury, C 1995. Background to genocide: Rwanda. Issue: A Journal of Opinion, 2(2):12-17.

Nkusi, L 2004. L'énoncé des sujets controversés dans l'histoire du Rwanda. In: D Byanafashe (ed.). Les défis de l'historiographie rwandaise. Tome 1: Les faits controversés. Butare: Editions de l'Université Nationale du Rwanda.

Parliament, The Senate 2005. Rwanda genocide ideology and strategies for its eradication. Kigali.

Parsa, AF 2004. Visual semiotics: How still images mean? Interpreting still images by using semiotic approaches. Paper presented at the 2nd International Symposium Communication in The Millennium: A Dialogue Between Turkish and American Scholars. In Cooperation with University of Texas, Anadolu University and İstanbul University.

Philips, I 2008. Teaching history. Developing as a reflective secondary teacher. Los Angeles: Sage.

Prince, MJ \& Felder, RM 2006. Inductive teaching and learning methods: Definitions, comparisons, and research bases. Journal of Engineering Education, 95(2): 123-138.

Prunier, G 1997. The Rwanda crisis: History of a genocide. London: C.Hurst.

Riessman, CK 1993. Narrative analysis: Qualitative research methods series. London, New Delhi: Sage Publications.

Republic of Rwanda 2013. Law No 84/2013 of 11/09/2013 on the crime of genocide ideology and other related offences. Official Gazette(43bis):31-44

Rutembesa, F 2011. Aspects pédagogiques de l'enseignement du génocide. In: CNLG (Ed.). 16 years after the genocide perpetrated against Tutsi (1994-2010). Kigali : CNLG.

Rwanda Education Board 2015a. History and citizenship syllabus for ordinary level s1s3. Kigali.

Rwanda Education Board 2015b. History syllabus for advanced level s4-s6. Kigali.

Smith, A 2012. The unique and universal aspects of modern genocide. In: P Cowan \& $\mathrm{H}$ Maitles (Eds.). Teaching controversial issues in the classroom: Key issues and debates. London: Bloomsbury Publishing.

Sebeok, TA 2001. Signs: An introduction to semiotics. Toronto: University of Toronto Press. 
Seetal, S 2005. Reconceptualising history teachers' identities within the context of changing curriculum. Unpublished thesis. Durban: University of KwaZuluNatal.

Sibomana J 2017. Hakenewe ubuvuzi bwihariye ku barokotse jenoside babana n'ihungabana n'ihahamuka kugirango batazanduza abazabakomokaho, Prof. Sezibera. Ikinyamakuru cya Komisiyo y'Igihugu yo Kurwanya Jenoside (CNLG), 13.

Straus, S 2001. Contested meanings and conflicting imperatives: A conceptual analysis of genocide. Journal of Genocide Research, 3(3):349-375.

Stradling, R 1984. The Teaching of controversial issues: An evaluation. Educational Review, 36(2):121-129.

Stradling, R 2003. Multiperspectivity in history teaching: A guide for teachers. Strasbourg: Council of Europe.

Tinsley-Myerscough, S \& Seabi, J 2012. The effect of a postmodern career life story intervention on disadvantaged Grade 12 learners. Paper presented at the South African Journal of Higher Education: 4th Annual South African Technology Network Conference 2011: Curriculum transformation at universities of technology: Towards development of new generation universities.

Thorsen M 2010. Teaching about genocide. A cross-curricular approach in art and history. Unpublished PhD thesis. Denver: University of Denver.

Totten, S 1987. The personal face of genocide: Words of witnesses in the classroom. Social Science Record, 24(2):63-67.

Totten, S 1999. Should there be Holocaust education for K-4 students? The answer is no. Social Studies and the Young Learner, 12(1):36-39.

Totten, S 2000. Diminishing the complexity and horror of the Holocaust: Using simulations in an attempt to convey historical experiences. Social Education, 64(3):165-171.

Türkcan, B 2013. Semiotic approach to the analysis of children's drawings. Educational Science: Theory Practice, 13(1):600-607.

Vandegintse, S 2014. Governing ethnicity after genocide: Ethnic amnesia in Rwanda versus ethnic power-sharing in Burundi. Journal of Eastern African Studies, 8:263-277. 
Wassermann, J 2011. Learning about controversial issues in school history: The experiences of learners in KwaZulu-Natal schools. Journal of Natal and Zulu History, (29):1-27.

Waterson RA 2009. The examination of pedagogical approaches to teaching controversial public issues: Explicitly the teaching of the Holocaust and comparative genocide. Social Studies Research and Practice, 2(1):1-24.

Webster, L \& Mertova, P 2007. Using narrative inquiry as a research method: An introduction to using critical event narrative analysis in research on learning and teaching. London: Routledge. 